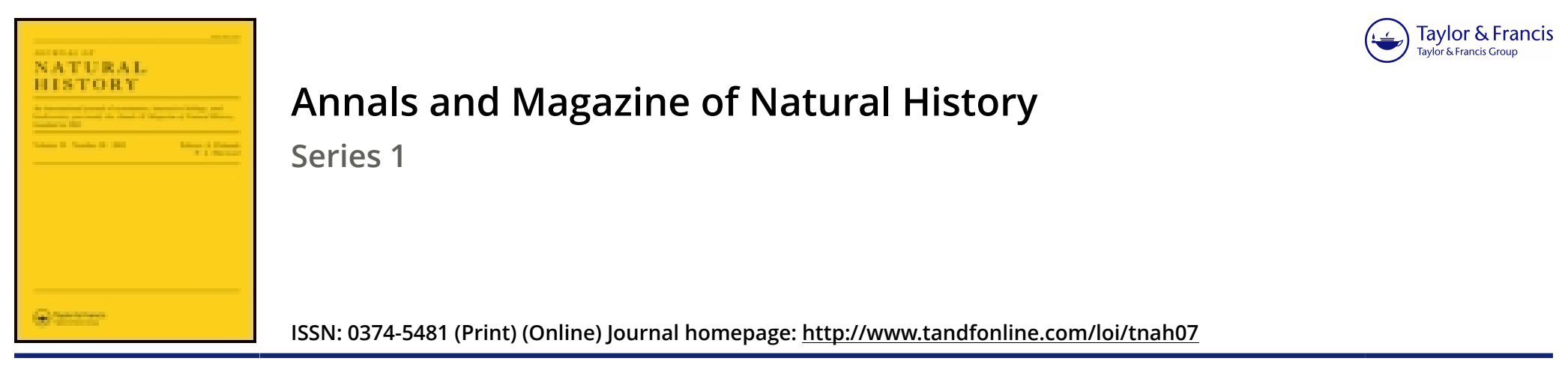

\title{
LVI._Catalogue of Irish entozoa, with observations
}

\section{O'Bryen Bellingham M.D.}

To cite this article: O'Bryen Bellingham M.D. (1845) LVI._Catalogue of Irish entozoa, with observations, Annals and Magazine of Natural History, 14:94, 471-479, DOI:

10.1080/037454809495229

To link to this article: http://dx.doi.org/10.1080/037454809495229

曲 Published online: 23 Dec 2009.

Submit your article to this journal $\longleftarrow$

Џ Article views: 2

Q View related articles 두 
ten cells, which are placed alternately opposite to the concave faces of the inner cells and the junction of their sides; in the former case they have three, and in the latter four faces besides the external margin.

When there is a third circle it generally consists of fifteen cells. In all the varieties the cells of the external circle are notched, and their segments more or less prolonged; but the length and form of the rays are very variable.

Meneghini describes several diaphanous vesicles in each cell.

Sometimes plants are met with having more than three circles; these are probably the Micrasterias elliptica, Ehr. Infus. p. 158. tab. 11. fig. 9, which Meneghini refers to the present species. I am not however satisfied that it is not distinct; the external cells agree with the description given above, but the inner ones are variable in number and not arranged in regular circles. Whether it possesses any other distinctive character I have not yet clearly ascertained. This form is fig. 21 of the 'American Bacillaria.'

Prate XII. fig. 7. P. Boryanum: $a$, central cell; $b$, a cell of the imer circle ; $\epsilon$, marginal cells.

PLATE XII.fig. 8. P. Boryanum, var. : $a$, central cell; $b$, marginal cells.

LVI.-Catalogue of Irish Entozoa, with observations. By O'BryeN Bellingham, M.D., Fellow of and Professor of Botany to the Royal College of Surgeons in Ireland, Member of the Royal Zoological, Geological and Natural History Societies of Dublin, \&c*.

ONE of the objects contemplated by the Natural History Society of Dublin on its formation, was to obtain, at as early a period as circumstances permitted, a complete catalogue of the animals, vertebral as well as invertebral, which are natives of this country. With the wish to contribute as far as lies in my power to so desirable an object, I have brought forward the following catalogue of Entozoa, or parasitic animals (a part of the invertebral kingdom which has not hitherto enjoyed much of the attention of British zoologists), which I have met with in this country, the great majority of them being new to the British fauna; in order to render it so far a perfeet list of our indigenous species, I have included a few which I have not been so fortunate as to find myself, but which have been noticed or described by others, particularly by Dr. Drummond, the President of the Belfast Natural History Society, whose talents have already contributed to ad-

* In order to complete Dr. Bellingham's Catalogue of Irish Entozoa, and to include all the species known in our volume for the current year, we have reprinted the first portion (containing the genera Filaria, Trichosoma, Trichocephalus, Oxyuris, and Cuculanus, ) which was originally published in Charlesworth's Magazine of Natural History.-ED. 
vance more than one branch of natural history, and who has lately turned his attention to these much-neglected animals, and has described some species altogether new to science.

Under the general name Entozoa (derived from évтòs, intus, $\xi \omega o v$, animal) are included all the animals which naturally and permanently reside in the alimentary canal, or some other part of the interior of animals. And although the habitat of any ani$\mathrm{mal}$ is not a sufficient ground to separate it from the genera or species which approach it in organization, yet as the Entozoa have been studied and described as a separate group by those naturalists whose authority upon the subject is the highest; and as the majority of them are distinct in organization from any animals not parasitic; and as we are as yet far from having arrived at a natural arrangement of invertebral animals (there being some groups which, though not parasitic, require to be associated with the Entozoa, and others which are parasitic, and which many have arranged with these animals, but of which the true situation is extremely doubtful);-it appeared to me to be more prudent to retain the term in the sense used by Rudolphi and Bremser; and on the present occasion I shall confine myself altogether to the true Entozoa, or those species which inhabit some part of the interior of the bodies of other animals; and I shall not enter at all upon the disputed point, as to the place which these animals ought to occupy in a natural arrangement of the invertebral kingdom.

The animals included under the term Entozoa, although they have been very carefully studied by several continental zoologists, and have occupied a considerable share of the attention of several distinguished comparative anatomists, have from some cause or other been little attended to, I might almost say completely overlooked by British naturalists, even by men distinguished in other departments of the science. "While there are some branches of natural history (as Mr. Jenyns has observed in his 'Report on Zoology') which are most sedulously cultivated by us, there are others which have for a long time lain comparatively neglected." This remark is peculiarly appropriate, and applies particularly to the animals which form the subject of the present communication ; they are commonly looked upon with disgust instead of anything of interest in a scientific point of view, and the number of individuals who have made them a study is exceedingly limited. Indeed, the little attention which the Entozoa have attracted in these countries will be apparent from the fact, that in the only works which contain lists of the British species, viz. Pennant's 'Zoology' and Turton's 'British Fauna,' but twenty-eight species are described as indigenous; and four of these are repeated twice under different names, leaving but twenty-four distinct species : 
while in the limited opportunities which I have had, I have detected and preserved upwards of 200 species, and several of these occurred in six, others in ten, and one species in as many as fifteen different animals.

The Entozoa, although they do not form a very numerous division of the animal kingdom, are very extensively distributed, as in almost all the mammalia, birds, reptiles and fish which $I$ have examined, I have detected some species, and often more than one; and there is scarcely a tissue or organ in which they do not sometimes occur.

I have found them in the œsophagus, stomach and intestines, in the bronchial tubes and air-cells of the lungs of some animals; in the urinary bladder, in the gall and swim-bladder of others; in cellular tissue and in serous membranes; in the substance of the heart, in the liver and kidney; some species inhabit the brain of animals, others their eyes, others aneurismal swellings of arteries, others the meatus auditorius, the frontal and maxillary sinuses, and even the cavity of the tympanum. In fact there is hardly an organ in which some species has not been detected, at least among vertebral animals ; and if they are more rare among the Invertebrata, it is, perhaps, because we have not yet sufficiently sought for them.

The number of animals which I have dissected in order to complete this list is very considerable; I possess notes of having examined upwards of 270 mammalia, 360 birds and 380 fish, exclusive of reptiles which are indigenous to this country. And here I have much pleasure in acknowledging the assistance which I have received from Mr. Richard Glennon, preserver of animals to the Natural History Society, who most obligingly placed at my disposal the body of any animal sent to him to be preserved which I was desirous of examining; indeed, without his kind co-operation, I could not have brought this list to its present extent.

The classification to which I have adhered in the following catalogue is the one given by Rudolphi in his 'Synopsis,' followed by Bremser in both his works, and adopted by almost all zoologists since. I cannot see the necessity for the change in the nomenclature of the orders which has been made by Mr. Owen, in his article Entozoa in the 'Cyclopædia of Anatomy and Physiology.' Rudolphi's terms are in a great measure established, having been adopted by almost every writer upon the subject since his time; and if the names of families or orders are to be altered upon trivial grounds, we should be under the necessity of giving up many of the names which have been longest established; indeed nothing appears to have a greater tendency to retard the study of natural history than the unnecessary multiplication of 
names which are already too numerous. But in the present instance I do not think the new names are an improvement upon the old ; the latter appear to me to be more expressive, and their having been adopted by the best practical helminthologists is a sufficient reason for retaining them here.

Rudolphi has arranged the Entozoa in five orders of families, each of which includes a larger or smaller number of genera. On the present occasion I shall only notice those genera in which I have as yet detected species inhabiting animals natives of this country.

Commencing with those most highly organized, they are $\mathrm{Ne}$ matoidea, Acanthocephala, Trematoda, Cestoidea, and Cystica.

\section{Order 1. NEMATOIDEA.}

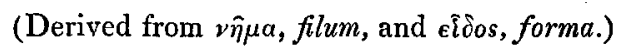

The order Nematoidea includes the Entozoa whose organization is the highest ; the body is cylindrical and elastic, more or less attenuated at each extremity; intestinal canal complete, provided with a mouth and anus; sexes distinct; commonly oviparous, rarely viviparous. The head is continuous with the body, very rarely separated by a neck, often obtuse and sometimes edged by lateral membranes (what Rudolphi has called winged). The posterior extremity of the body is either sharp or obtuse, often curved. The male is almost always smaller than the female, and the penis, which is either a single or double spiculum, frequently projects externally. In both sexes the internal organs of generation (the ovaries in the female and the seminal tubes in the male) are in the form of long filaments, which surround the intestinal canal. The generic characters are taken principally from the shape of the mouth, or from the disposition of the tubercles which surround it, the absence or presence of lips, \&c.

The genera in this order are found in all classes of animals; they inhabit almost every organ, but most frequently the alimentary canal.

\section{Genus 1. Filaria.}

(Derived from filum, a thread.)

Body long, cylindrical and elastic, nearly of equal diameter throughout; mouth orbicular. Male organ a simple spiculum.

This genus was established by Müller, and has been adopted by Rudolphi ; the species inhabit cellular membrane in every part of the body, very rarely the alimentary canal; they are not uncommon in mammalia, birds and fish, they are less common in reptiles; they occur also in invertebral animals, particularly in the larva of Lepidoptera, and in some Coleoptera. 
The Filaria have been arranged by Rudolphi in two sudivisions, according as the mouth is simple or papillary and labiate.

Ore simplici.

1. Filaria attenuata. $\left\{\begin{array}{l}\text { Cellular membrane in abdomen of peregrine } \\ \text { falcon (Falco peregrinus). }\end{array}\right.$ Species dubice.

2. Filaria*. Peritoneum of red gurnard (Trigla Pini).

3. - †. Peritoneum of mullet (Mugil Capito).

4. - ? $\ddagger$ Abdominal cavity of bee (Bombus terrestris).

Genus 2. Trichosoma.

(Derived from $\theta$ pi $\xi$, capillus.)

Body cylindrical and elastic, of moderate length, very slender towards the anterior extremity, and insensibly enlarging posteriorly. Mouth terminal, punctiform. Male organ a simple filament contained in a sheath.

This genus was established by Zeder, under the name of $C a$ pillaria. The species are most common in birds, next in the mammalia; they are very rare in reptiles and fish; they inhabit the stomach, the small and large intestines, sometimes the urinary

* This species of Filaria (which does not appear to have been described) occurred under the peritoneum of the common red gurnard (Trigla Pini). The specimens which I possess are from three to four inches in length, and about the thickness of strong thread; the colour white, body cylindrical, and of the same diameter throughout. Anterior extremity obtuse and rounded, posterior acute. Mouth orbicular and very small. In removing them, some ruptured, and allowed the ovaries and intestinal canal to protrude.

+ This species (which also appears not to have been described) occurred in the peritoneum of the common gray mullet (Mugil Capito) ; they were so imbedded in this membrane that it required considerable trouble to remove them, and some portion of the membrane continued to adhere to them, which rendered their examination difficult; they are about $4 \frac{1}{2}$ lines in length, colour white, body slender, and of the same diameter throughout. Anterior and posterior extremity rounded, mouth obscurely orbicular; a slight prominence near the posterior extremity, at which the anus appeared to open.

$\ddagger$ This species I have met with upon several occasions in the cavity of the abdomen of the common humble bee (Bombus terrestris), and sometimes in very large numbers; they lived and moved about in a watch-glass containing water for a considerable time; they are cylindrical, some are smaller than others, and in these the posterior extremity is very slightly curved, in the larger (which probably are females) this part is straight. They are so small as to be hardly visible without a lens, and in consequence of this I have not been able to succeed in seeing the shape of the mouth; hence they may probably eventually turn out to belong to some other genus. 
bladder. The species of the genus Trichosoma are all exceedingly small and resemble each other very closely (almost the only difference being a little greater or less length or thickness of the body), and as male and female are not always found together, it is very difficult to determine the species accurately ; in fact, of the twenty-two species which Rudolphi has enumerated, sixteen are doubtful; and of thirteen species which I have met with nine are doubtful.

1. Trichosoma obtusum? Cæea of horned owl (Otus vulgaris).

2. inflexum?. $\left\{\begin{array}{c}\text { Small intestine of missel thrush (Turdus } \\ \text { viscivorus. }\end{array}\right.$

3. longicolle? $\left\{\begin{array}{c}\text { Small intestine of domestic fowl (Gallus } \\ \text { domesticus). }\end{array}\right.$

4. _ plica $\ldots\left\{\begin{array}{l}\text { Urinary bladder of dog (Canis familiaris). } \\ \text { Urinary bladder of fox (Canis Vulpes). }\end{array}\right.$

Species dubia.

5. Trichosoma ..... Urinary bladder of wild cat (Felis Catus).

6. $\ldots \ldots\left\{\left\{\begin{array}{l}\text { Small intestines of weasel (Mustela vul- } \\ \text { garis). }\end{array}\right.\right.$

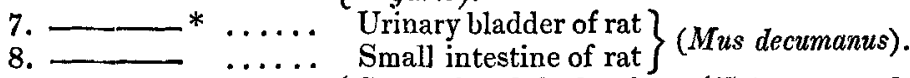

9. $\left\{\begin{array}{c}\text { Stomach of hedge-hog (Erinaceus vul- } \\ \text { garis). }\end{array}\right.$

* This species of Trichosoma I have very frequently found in the urinary bladder of the common Norway rat; in some cases only one or two occurred, in others six, eight or upwards. Many were free in the bladder; others so firmly attached by their anterior extremity to the mucous membrane, that they broke across when pulled; and some even remained adherent after having been placed in spirits of wine. They are the largest species of Trichosuma which I have seen, the posterior division of the body in some being so thick as in a certain degree to resemble this part in the Trichocephalus, from which, however, they are readily distinguished, the increase in diameter being gradual, and not sudden. They are about 8 lines in length, the body white and cylindrical, the posterior extremity rounded; in the thicker part of the body the alimentary canal appears to be somewhat spiral, and is surrounded by the convoluted ovaries. All the specimens which $I$ have appear to be females.

This species has not, I believe, hitherto been described, although it is very common, and I have frequently met with it. It occurs in the urinary bladder, both of the male and female rat, and is quite distinct from the species which inhabits the small intestine of the same animal.

From the thickness of the posterior part of the body compared with other species of Trichosoma, I would venture to suggest for this species the name Trichosoma crassicauda. 


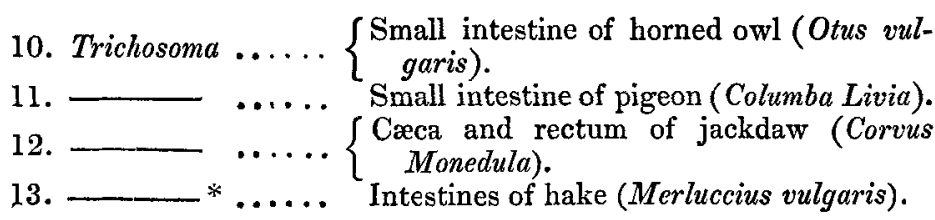

Genus 3. Trichocephalus.

(Derived from $\theta \rho i \xi$, capillus, and $\kappa \epsilon \phi a \lambda \grave{\eta}$, caput.)

Body cylindrical and elastic, anterior portion capillary and suddenly passing into the thicker or posterior part (by this it is distinguished from the genus Trichosoma, in which the increase is very gradual); mouth orbicular; penis simple, contained in a sheath.

The name Trichocephalus was given to this genus by Goetze, and adopted by Rudolphi. It was formerly named Trichurus (from $\theta$ oi $\xi$, capillus, and oupà, cauda), from the erroneous supposition that the capillary portion was the tail. The species inhabit the large intestines, particularly the cxcum of the mammalia; they do not occur in either birds or fish. The genus is not numerous in species. Rudolphi has arranged them in two subdivisions; our native species belong only to one of these subdivisions.

1. Trichocephalus dispar $\uparrow \ldots$ Large intestines of $\operatorname{man}($ Homo).

* The genus Trichosoma is very rare in fish ; Rudolphi or Bremser has never found them; the only species which has been as yet described to occur in these animals, is one noticed by Creplin in his ' Observationes de Entozois.' This species I found in the intestines of the hake (Merluccius vulgaris); the longest specimen is upwards of an inch in length, the body slender, colour perfectly white. As there cannot be a doubt that it is a new species, I would venture to suggest the name Trichosoma gracilis for it.

$\uparrow$ The Trichocephalus dispar has been longer known than any other species of the genus; and although stated by several writers to be rare in these countries, in the course of my experience $I$ have found it by far the most common species inhabiting the alimentary canal of the human subject. I have examined the intestinal canal of ninety individuals, who died in St. Vincent's Hospital, Dublin, of various diseases, and whose ages varied from three years to seventy; and in eighty-one out of the ninety, I found a larger or smaller number of this species; sometimes only one or two existed, sometimes they were in considerable abundance ; the largest number I have met with in the same individual was 119; sometimes they were attached to the mucous membrane, more commonly they were free; they almost always inhabited the large intestine, particularly the creum; I have, however, met with them in the small intestine. The male appears to be as common, or perhaps more common than the female, which is contrary to what happens in most other genera of Nematoidea. 
2. Trichocephalus crenatus* .. Cæecum of pig (Sus Scrofa).

3. — nodosus .... Cæcum of mouse (Mus Musculus).

\section{Genus 4. Oxyurus.}

(Derived from ósis, acutus, and oìpà, cauda.)

Body cylindrical and elastic, the posterior extremity subulate in the female; mouth orbicular and terminal; male organ contained in a sheath.

The genus Oxyurus was established by Rudolphi; it contains a very small number of species, only three being enumerated by Rudolphi in his 'Synopsis.' The species inhabit the large intestines of the mammalia, and have not been found in either birds, reptiles or fish.

1. Oxyurus curvula $\nmid \ldots \ldots\left\{\begin{array}{c}\text { Large intestine of horse (Equus Ca- } \\ \text { ballus). }\end{array}\right.$ 2. __ ambigua $\ddagger \ldots . .$. Cæcum of rabbit (Lepus Cuniculus).

\section{Genus 5. Cucullan us.}

(Derived from cucullus, a hood.)

Body cylindrical and elastic, obtuse anteriorly, more attenuated posteriorly; mouth orbicular; head provided with a striated cucullus (from which circumstance the genus has been named); anus terminal; orifice of female organs a little behind the centre of the body ; male organ a double spiculum; all the species viviparous.

The name Cucullus was given to this genus by Müller; the species inhabit the alimentary canal of fish, and do not occur in either mammalia or birds.

1. Cucullanus elegans $\S . .\left\{\begin{array}{l}\text { Stomach, intestines and pyloric appen- } \\ \text { dages of perch (Perca fuviatilis). } \\ \text { Intestines of eel (Anguilla acutirostris). }\end{array}\right.$

* This species resembles pretty closely the Trichocephalus dispar; the capillary portion of the animal is, however, a little longer, and the sheath of the penis has a somewhat different shape from what it has in that species.

+ The Oxyurus curvula is noticed in Pennant's 'British Zoology' under the name of Trichocephalus Equi; it is the largest species of the genus, inhabiting the great intestine of the horse, and is not at all uncommon.

\$ I have found the Oxyurus ambigua in great numbers in the cxcum of the common wild rabbit; the females are double the length of the males, and much more numerous. The mouth is orbicular and very small; on each side of the head is a transparent membrane, somewhat resembling that of the Ascaris vermicularis.

$\$$ The Cuculbanus elegans is very common in the perch, occurring 
2. Cucullanus foveolatus*. $\left\{\begin{array}{l}\text { Intestines of plaice (Patessa vulgaris). } \\ \text { Intestines of dab (Platessa Limanda). }\end{array}\right.$

in the stomach, intestines and pyloric appendages. The species is viviparous, as when some of the females have been accidentally cut across, I have seen the young come out in great numbers, and move about freely in water placed in a watch-glass.

The Cucullanus elegans is more rarely met with in the eel than in the perch ; sometimes they were free in the intestinal canal, at others attached to the mucous membrane almost as firmly as Echinorhynchi. They were of a reddish colour, the head a deeper red than the body; after remaining in water for some time, every part became white except the head.

The female Cucullanus elegans from the eel is about $4 \frac{1}{2}$ lines in length, the male about 2 lines. The head is rounded, and is pretty accurately represented in the magnified figure in Bremser's large work. The stria upon the cucullus are numerous and run longitudinally; the mouth is orbicular, in some a small papilla projected; the csophagus is narrow at its commencement, and runs in a straight line to the stomach, which is somewhat oblong and double the diameter of the cosophagus; the intestine is straight, the anus is situated near the posterior extremity. The vulva in the female is conspicuous, projecting, seated nearer the caudal than the anterior extremity of the body; the penis of the male (in the specimens which I met with) did not project externally. In the female the caudal extremity is rather sharp, not obtuse as Rudolphi describes it to be; it is straight in the female, inflexed in the male.

* The Cucullanus foveolatus from the plaice, in some instances, adhered firmly to the mucous membrane of the intestine; very soon after being placed in water, the integuments ruptured and allowed the ovaries, \&c. to protrude. I have not observed that this species is viviparous.

The Cucullanus foveolatus from the dab is perfectly white, of equal diameter throughout, except at the extremities. The females are from 6 to $6 \frac{1}{2}$ lines in length, the males rather less; the anterior extremity is obtuse, the posterior acute in both sexes; the caudal extremity in the female is straight, incurved in the male. The cosophagus is longer and wider than the stomach ; it contracts suddenly where it joins the latter organ; the stomach is cylindrical; the anus in the female is close to the caudal extremity, in the male it is a little more anterior, and projects considerably; the orifice by which the penis protrudes is seated between the anus and the caudal extremity. The penis is a double spiculum, very sharp, fine and white; the vulva in the female is situated nearer the caudal than the anterior extremity. Several of the females, after remaining for a short time in water (in which they at first moved about, but soon died), ruptured, and the intestine and ovaries protruded. 